Available online at: http://journal.unj.ac.id

Jurnal

Pensil

Pendidikan Teknik Sipil

Journal homepage: http://journal.unj.ac.id/unj/index.php/ipensil/index

\title{
PENGARUH SUASANA LINGKUNGAN BELAJAR TERHADAP KONSENTRASI BELAJAR SISWA DALAM MATA PELAJARAN PRODUKTIF
}

\section{'THE INFLUENCE OF A LEARNING ENVIRONMENT ON STUDENTS' LEARNING CONCENTRATION IN PRODUCTIVE SUBJECTS}

\author{
Parlin Tambunan 1 , M Fikry Ardhiansyah², Muhammad Galviando Kurianawan ${ }^{3}$ \\ ${ }^{1,2}$ SMK Negeri 6 Kota Bekasi \\ ${ }^{3}$ Indonesia University of Education \\ 12parlintambunan0@,gmail.com, ${ }^{2}$ mfikryardhiansyah@gmail.com \\ galviandokurniawan@,gmail.com
}

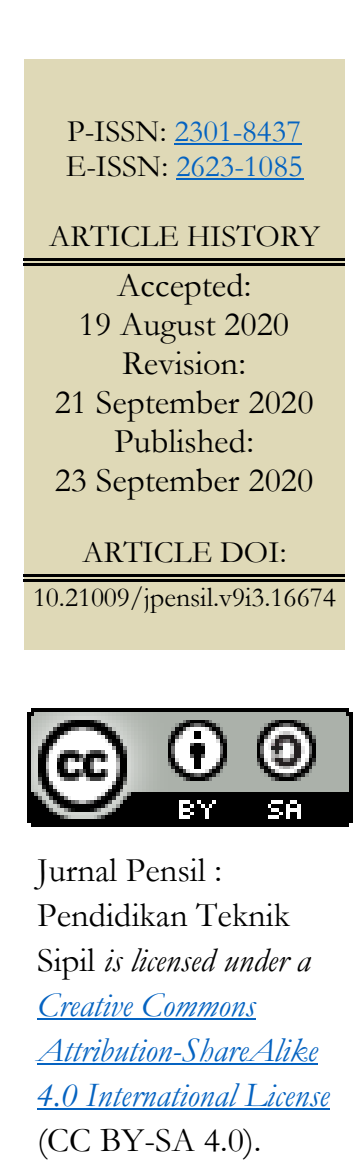

Abstrak

Penelitian ini mengkaji masalah konsentrasi belajar siswa yang kurang optimal pada Program Perencanaan dan Informasi Bangunan (DPIB) di SMK Negeri 6 Kota Bekasi. Tujuan penelitian ini adalah untuk mengetahui suasana lingkungan belajar, gambaran konsentrasi belajar siswa, dan seberapa besar suasana lingkungan belajar tentang konsentrasi belajar siswa Program DPIB di SMK Negeri 6 Kota Bekasi ditinjau dari aspek lingkungan belajar. Penelitian ini menggunakan metode korelasional dengan pendekatan kuantitatif, instrumen pengumpulan data yang digunakan berupa polling tentang suasana lingkungan belajar (variabel X) dan konsentrasi belajar (variabel Y). Jumlah responden dalam penelitian ini adalah 56 responden yang merupakan siswa program XI DPIB di SMK Negeri 6 Kota Bekasi. Teknik analisis data yang digunakan adalah uji trends, uji signifikansi, dan analisis regresi sederhana. Hasil pengolahan data menunjukkan bahwa gambaran lingkungan belajar berada pada kategori sedang dengan nilai persentase sebesar $26,786 \%$ sedangkan pada gambar pembelajaran konsentrasi siswa berada pada kategori sedang dan tinggi dengan nilai persentase sebesar 23,214\%. Berdasarkan hasil perhitungan uji signifikansi diperoleh hasil bahwa suasana lingkungan belajar berpengaruh positif dan signifikan terhadap konsentrasi belajar siswa. Besarnya pengaruh lingkungan belajar terhadap konsentrasi belajar ditunjukkan dengan koefisien determinasi sebesar 24,561\%.

Kata kunci: Lingkungan Belajar (Siswa), Konsentrasi Belajar (Siswa)

\section{Abstract}

This study examines the problem of less optimal student learning concentration of The Modeling and Building Information Program Design (DPIB) at SMK Negeri 6 Bekasi City. The purpose of this research is to know the atmosphere of learning environment, the description of students' learning concentration, and how much the environmental atmosphere is learning about the learning concentration of students 
DPIB Program at SMK Negeri 6 Bekasi City is reviewed from the environmental aspects of the learning environment. The research uses correlational methods with a quantitative approach, the data collection instruments used in the form of a poll about the atmosphere of learning environment (variable X) and learning concentration (variable Y). The number of respondents in this study was 56 respondents who were students of the XI DPIB program in SMK Negeri 6, Bekasi City. The data analysis techniques used are trend testing, significance testing, and simple regression analysis. The results of data processing show that the overview of the learning environment is in the category of medium with a percentage value of $26.786 \%$ while in the picture learning concentration of students are in medium and high category with value Percentage of $23.214 \%$. Based on the results of the calculation of significance test, the result that the atmosphere of learning environment has a positive and significant influence on student learning concentration. The magnitude of environmental influence learning to learn concentration is demonstrated by the coefficient of determination of $24.561 \%$.

Keywords: (student) Learning environment, (student) learning concentration

\section{Pendahuluan}

Berkaitan dengan pendidikan, sebagaimana yang diketahui bahwa kegiatan belajar mengajar di sekolah, baik sekolah dasar maupun sekolah menengah pasti mempunyai target hasil belajar yang harus dicapai oleh setiap siswa berdasarkan kurikulum yang berlaku pada saat itu. Berdasarkan UU No. 20 Tahun 2003 mengenai sistem pendidikan nasional dalam pasal 3, bahwa "Tujuan pendidikan nasional adalah mengembangkan potensi peserta didik agar menjadi manusia yang beriman dan bertakwa kepada Tuhan Yang Maha Esa, berakhlak mulia, sehat, berilmu, cakap, kreatif, mandiri, dan menjadi warga negara yang demokratis serta bertanggung jawab". Setiap siswa mempunyai

keterampilan yang berbeda-beda dalam hal belajar, seperti keterampilan membaca, mendengar, dan menulis yang mereka peroleh dari pengalaman belajarnya yang sudah pasti akan berpengaruh dengan prestasi belajar. Setiap siswa mempunyai karakter yang berbeda-beda ketika mereka harus mengikuti proses belajar di kelas. Siswa yang cenderung asyik dengan dunianya sendiri, mereka lebih suka mengobrol dengan teman duduknya daripada harus mendengarkan materi yang diberikan oleh guru, ada siswa yang hanya bisa fokus terhadap pelajaran jika suasana tenang, dan sejenisnya. Siswa hendaknya mampu berkonsentrasi saat proses belajar mengajar berlangsung, seperti yang diungkapkan oleh Slameto (2013, hlm. 87) "konsentrasi belajar besar pengaruhnya terhadap belajar. Jika seseorang mengalami kesulitan berkonsentrasi, jelas belajarnya akan sia-sia, karena hanya membuang tenaga, waktu dan biaya saja". Seperti yang dikemukakan oleh Slameto (2013, hlm. 77) "tempat belajar hendaknya tenang, jangan diganggu oleh perangsangperangsang dari sekitar. Artinya, suasana yang dimaksud adalah suasana pembelajaran yang kondusif'. Kondusif berarti benarbenar mendukung keberlangsungan proses pembelajaran. Suasana saat proses belajar dapat mempengaruhi efisiensi waktu belajar. Dengan suasana yang kurang kondusif akan membuat siswa tidak fokus terhadap proses pembelajaran sehingga waktu belajar pun tidak efektif. Sejalan dengan ini, Mulyasa (2009, hlm. 76) "lingkungan yang kondusif merupakan tulang punggung dan faktor 
pendorong yang dapat memberikan daya tarik tersendiri bagi proses belajar, sebaliknya lingkungan yang kurang menyenangkan akan menimbulkan kejenuhan dan rasa bosan". Artinya, lingkungan sekolah yang kondusif sangat diperlukan agar tercipta proses pembelajaran yang bermakna seperti kelas yang layak pakai, minim terdapatnya kebisingan dari dalam dan luar kelas, pencahayaan yang cukup, dan keadaan cuaca yang dapat diterima oleh siswa.

Suasana lingkungan belajar merupakan perangsang bagi siswa untuk lebih berkonsentrasi dalam belajar. Dengan suasana lingkungan yang kondusif maka konsentrasi dalam belajar itu akan meningkat dan dapat mendorong siswa dalam memahami bahan ajar yang diberikan oleh tenaga pendidik. Artinya konsentrasi merupakan dorongan untuk melakukan sebuah kegiatan belajar agar siswa dapat memahami bahan ajar dengan maksimal. Keadaan lingkungan yang tidak kondusif akan menghambat siswa dalam memperhatikan pelajaran di kelas. Menurut Dimyati dan Mudjiono (2013, hlm. 42) "perhatian mempunyai peranan yang penting dalam kegiatan belajar".

Berdasarkan hasil pengamatan peneliti ketika melakukan observasi di jurusan Desain Pemodelan dan Informasi Bangunan (DPIB) SMK Negeri 6 Bekasi, peneliti mengamati perilaku siswa kelas XI DPIB di saat proses belajar mengajar berlangsung. Kondisi siswa di kelas tersebut kurang kondusif dan dapat dikatakan siswa belum mampu berkonsentrasi belajar dengan baik karena terdapat siswa yang melamun saat diberikan materi pelajaran, bermain-main ketika pelajaran, tidak memperhatikan guru, beberapa juga ada yang mengobrol dengan teman sebangkunya, dan suasana kelas yang cukup panas atau gerah.

Berdasarkan hal tersebut, peneliti berupaya meneliti pengaruh suasana lingkungan belajar terhadap konsentrasi belajar. Penulis ingin menjadikan mata pelajaran konstruksi dan utilitas bangunan menjadi lebih optimal, hal ini sebagai langkah penulis membantu Indonesia dalam meningkatkan kualitas Pendidikan nasional, untuk itu penulis membuat suatu penelitian pendidikan dengan judul

"Pengaruh Suasana Lingkungan Belajar terhadap Konsentrasi Belajar Siswa dalam Mata Pelajaran Konstruksi dan Utilitas Bangunan (Siswa Kelas XI DPIB SMK Negeri 6 Bekasi)".

\section{Rumusan Masalah}

Berdasarkan latar belakang dari judul "Pengaruh Suasana Lingkungan Belajar terhadap Konsentrasi Belajar Siswa dalam Mata Pelajaran Produktif (Siswa Kelas XI DPIB SMK Negeri 6 Bekasi)" di atas, identifikasi permasalahan yang didapat yaitu antara lain sebagai berikut: 1 . Perilaku siswa yang muncul selama mengikuti proses pembelajaran tetapi tidak mendukung kegiatan belajar. 2. Suasana lingkungan belajar yang tidak kondusif. 3. Kondisi kelas yang kurang layak pakai 4. Pencahayaan yang kurang. 5. Sirkulasi udara yang kurang sehingga menyebabkan kelas menjadi gerah. 6. Kebisingan suara dari luar maupun dalam kelas. 7. Siswa yang tidak dapat berkonsentrasi dengan maksimal. 8. Belum diketahuinya pengaruh suasana lingkungan belajar terhadap konsentrasi belajar.

\section{Metode Penelitian}

Berdasarkan pada permasalahan yang diteliti, metode yang digunakan dalam penelitian ini adalah metode penelitian korelasional dengan pendekatan kuantitatif. Menurut Emzir (2009, hlm. 46) "penelitian korelasional mengacu pada studi yang bertujuan mengungkapkan hubungan antarvariabel melalui penggunaan statistik korelasional". Menurut Arikunto (2010) "penelitian korelasional ialah penelitian yang dilakukan oleh peneliti untuk mengetahui tingkat hubungan antara dua variabel atau lebih tanpa melakukan perubahan, tambahan atau manipulasi terhadap data yang memang sudah ada" 


\section{Hasil Penelitian dan Pembahasan}

Untuk mencapai keberhasilan belajar atau efektifitas pembelajaran dipengaruhi oleh banyak faktor, di antaranya adalah suasana lingkungan belajar. Suasana merupakan penilaian keadaan lingkungan belajar yang bagus atau tidaknya suatu tempat dari yang melihat ataupun yang merasakannya.

Tabel 1. Data Responden

\begin{tabular}{llll}
\hline No. & Kelas & $\begin{array}{c}\text { Sampel } \\
\text { Penelitian }\end{array}$ & $\begin{array}{c}\text { Jumlah } \\
\text { Responden } \\
\text { yang } \\
\text { Digunakan }\end{array}$ \\
\hline 1. & XIDPIB 1 & 28 orang & 28 orang \\
\hline 2. & XI DPIB 2 & 28 orang & 28 orang \\
\hline Jumlah & 56 orang & 56 orang \\
\hline
\end{tabular}

Berdasarkan data mentah untuk variabel $\mathrm{X}$ yang terkumpul dari hasil penyebaran angket bersifat tertutup kepada 56 responden (Tabel 1.), dengan jumlah butir pernyataan sebanyak 35 butir yang dibagi kedalam 5 indikator, pemberian skor menggunakan skala likert dimana pernyataan yang bersifat positif (skor $4-1$ ) sedangkan pernyataan yang bersifat negatif (skor 1 - 4) maka dapat diketahui prosentase skor dari masing-masing indikator seperti Tabel 2.

Tabel 2. Per Indikator Variabel X (Konsentrasi Belajar)

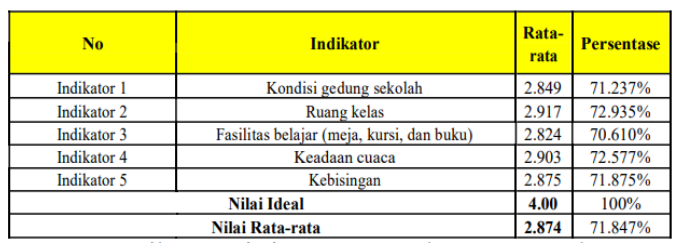

Gambar 1. merupakan gambar diagram batang per indikator dari variabel Suasana Lingkungan Belajar (X), dimana perolehan rata-rata skor terbesar pada hasil penyebaran angket penguasaan Suasana Lingkungan Belajar adalah sebesar 72,57\% pada indikator ruang kelas.

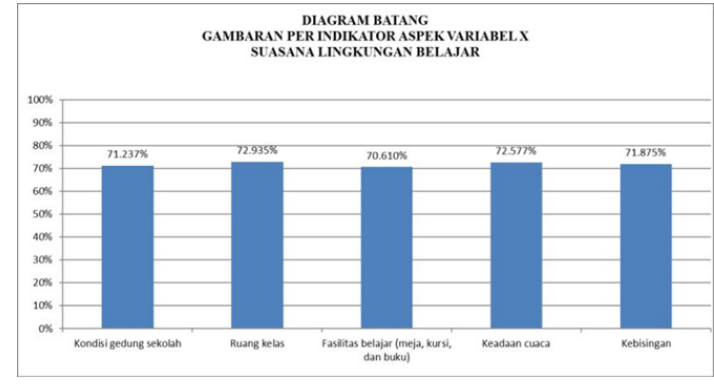

Gambar 1. Presentase Gambaran Per Indikator Variabel X.

\section{Deskripsi Hasil Mengenai Konsentrasi} Belajar.

Berdasarkan data mentah untuk variabel $\mathrm{Y}$ yang terkumpul dari hasil penyebaran angket bersifat tertutup kepada 56 responden, dengan jumlah butir pernyataan sebanyak 35 butir yang dibagi kedalam 9 indikator, pemberian skor menggunakan skala likert dimana pernyataan yang bersifat positif (skor $4-1$ ) sedangkan pernyataan yang bersifat negatif (skor 1 - 4) maka dapat diketahui prosentase skor dari masing-masing indikator sebagai berikut:

Tabel 3. Indikator Variabel Y (Konsentrasi Belajar)

\begin{tabular}{|c|c|c|c|}
\hline No & Indikator & Rata-rata & Persentase \\
\hline Indikator 1 & Memberikan perhatian yang penuh saat proses belajar & 2.643 & $66.071 \%$ \\
\hline Indikator 2 & Mampu fokus terhadap pelajaran secara terus-menerus & 2.688 & $67.188 \%$ \\
\hline Indikator 3 & Memperhatikan dan menghormati orang lain ketika berbicara & 2.854 & $71.339 \%$ \\
\hline Indikator 4 & Mengikuti petunjuk yang diberikan guru & 2.657 & $66.429 \%$ \\
\hline Indikator 5 & Mampu mengatur tugas-tugas dan kegiatan-kegiatannya & 2.800 & $70.000 \%$ \\
\hline Indikator 6 & Tidak malas mengerjakan tugas & 2.804 & $70.089 \%$ \\
\hline Indikator 7 & Mampu menjaga barang-barang miliknya & 2.583 & $64.583 \%$ \\
\hline Indikator 8 & Tidak mudah terusik olch kegaduhan & 2.714 & $67.857 \%$ \\
\hline Indikator 9 & Tidak pelupa & 2.810 & $70.238 \%$ \\
\hline \multirow{2}{*}{\multicolumn{2}{|c|}{$\begin{array}{c}\text { Nilai Ideal } \\
\text { Nilai Ratarat }\end{array}$}} & 4.00 & $100.0 \%$ \\
\hline & & 2.728 & $68.199 \%$ \\
\hline
\end{tabular}

Berdasarkan Tabel.3 dapat diketahui bahwa perolehan rata-rata skor terbesar pada hasil penyebaran angket Konsentrasi Belajar adalah sebesar $71,339 \%$ pada indikator memperhatikan dan menghormati orang lain ketika berbicara. Berikut ini merupakan gambar diagram batang per indikator dari variabel Konsentrasi Belajar: 


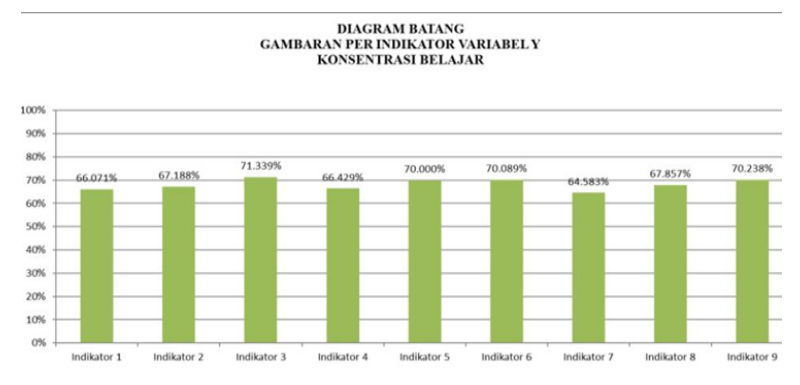

Gambar 2. Presentase Gambaran Per Indikator Variabel Y

Setelah data per indikator telah didapatkan, kemudian konversikan data tersebut kedalam skor baku. Berikut merupakan tabel hasil konversi variabel $\mathrm{X}$ dan $Y$, terdapat jumlah responden, nilai rata-rata, nilai simpangan baku, nilai minimum, nilai maksimum, nilai median serta nilai modus masing-masing variabel.

Tabel 4. Data Responden Antar Variabel X dan Y

\begin{tabular}{|c|c|c|c|c|c|c|c|c|}
\hline Var. & Resp. & Mean & Modus & Median & SD & Min. & Maks. & $\begin{array}{c}\text { Jumlah } \\
\text { Skor }\end{array}$ \\
\hline $\mathrm{X}$ & 56 & 50,0 & 65,2 & 50,6 & 9,651 & 29,9 & 68,2 & 4100 \\
\hline Y & 56 & 50,0 & 53,9 & 50,8 & 10,200 & 29,1 & 69,0 & 4100 \\
\hline
\end{tabular}

Deskripsi Hasil Uji Kecenderungan

Uji kecenderungan dimaksudkan untuk menghitung kecenderungan umum dari setiap variabel sehingga dapat diperoleh gambaran dari masing-masing variabel yang diteliti.

Kecenderungan Variabel X (Suasana Lingkungan Belajar)

Data variabel $\mathrm{X}$ merupakan gambaran tentang suasana lingkungan belajar kelas XI program DPIB di SMK Negeri 6 Kota Bekasi.

$\begin{aligned} \text { Jumlah responden } & =56 \text { orang } \\ \mathrm{X} & =49,064 \\ \text { Skor maksimum } & =68,2 \mathrm{SD} \\ \text { Skor minimum } & =6,387 \\ & =29,9\end{aligned}$

Tabel 5. Data Responden Antar Variabel X dan Y

\begin{tabular}{|c|c|c|c|c|c|c|c|c|}
\hline No & Skala Skor Mentah & Nilai Matang & \multicolumn{3}{|c|}{ Tabel Konversi } & Kriteria & $\mathrm{F}$ & $\%$ \\
\hline 1 & $X_{\text {rabratal }}+1,5 S D$ & 58.644 & 58.644 & $\langle x|$ & & Sangat Tinggi & 13 & $23.214 \%$ \\
\hline 2 & $x_{\text {fraternate }}+0,5 S D$ & 52.257 & 52.257 & $\leq x \leq$ & 58.644 & Tinggi & 111 & $19.643 \%$ \\
\hline 3 & $X_{\text {ratardate }}-0,5 S D$ & 45.870 & 45.870 & $\langle x| \leq$ & 52.257 & Sedang & 15 & $26.786 \%$ \\
\hline 4 & $X_{\text {raterafta }}-1,5 S D$ & 39.483 & 39.483 & $|x| \leq$ & 45.870 & Rendah & 8 & $14.286 \%$ \\
\hline 5 & & & & $x \mid \leq$ & 39.483 & Sangat Rendah & 9 & $16.071 \%$ \\
\hline \multicolumn{7}{|c|}{ mar } & 56 & $100 \%$ \\
\hline
\end{tabular}

Berdasarkan Tabel.5 mengenai gambaran umum suasana lingkungan belajar Program DPIB di SMKN 6 Kota Bekasi, dapat dideskripsikan bahwa suasana lingkungan belajar pada kategori sangat tinggi sebanyak 13 responden (23,214\%), kategori tinggi sebanyak 11 responden $(19,643 \%)$, kategori sedang sebanyak 15 responden (26,786\%), kategori rendah sebanyak 8 responden $(14,286 \%)$, dan kategori sangat rendah sebanyak 9 responden $(16,071 \%)$. Dari hasil persentase di atas, maka secara umum dapat diperoleh bahwa suasana lingkungan belajar DPIB di SMKN 6 Kota Bekasi cenderung tersebar pada kategori sedang dengan nilai presentase $(26,786 \%)$.

Berikut diagram dan presentase distribusi data variabel suasana lingkungan belajar DPIB di SMKN 6 Kota Bekasi berdasarkan sebaran angket.

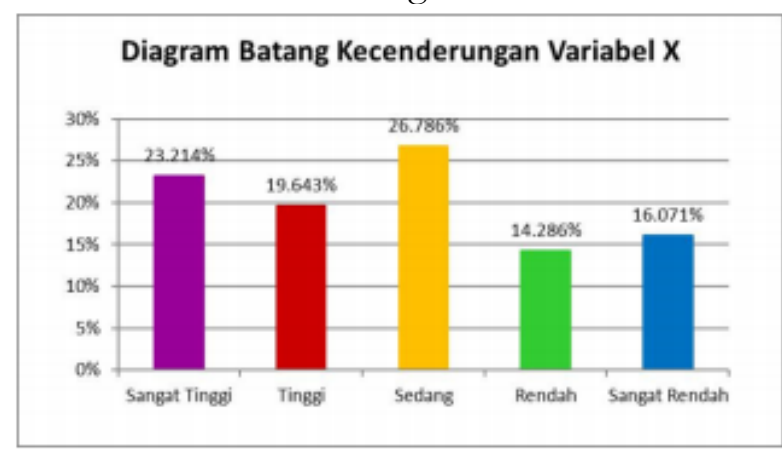

Gambar 3. Diagram Batang Kecenderungan Variabel X

Kecenderungan Variabel Y (Konsentrasi Belajar) 
Data variabel Y merupakan gambaran tentang konsentrasi belajar siswa kelas XI DPIB di SMK Negeri 6 Kota Bekasi.

$\begin{aligned} \text { Jumlah responden } & =56 \text { orang } \\ \mathrm{X} & =49,035 \\ \text { Skor maksimum } & =68,97 \mathrm{SD} \\ & =6,645 \\ \text { Skor minimum } & =29,09\end{aligned}$

Tabel 6. Uji Kecenderungan Variabel Y (Konsentrasi Belajar)

\begin{tabular}{|c|c|c|c|c|c|c|c|c|c|}
\hline No & Skala Skor Mentah & Nilai Matang & \multicolumn{4}{|c|}{ Tabel Konversi } & Kriteria & $\mathrm{F}$ & $\%$ \\
\hline 1 & $\mathrm{X}_{\text {retar-ata }}+1,5 \mathrm{SD}$ & 59.003 & 59.003 & $x$ & & & Sangat Tinggi & 12 & $21.429 \%$ \\
\hline 2 & $x_{\text {ratarate }}+0,5 \mathrm{SD}$ & 52.358 & 52.358 & $x$ & $\leq$ & 59.003 & Tinggi & 13 & $23.214 \%$ \\
\hline 3 & $x_{\text {ratarata }}-0,550$ & 45.712 & 45.772 & $\mathrm{x}$ & $\leq$ & 52.358 & dang & 13 & $23.214 \%$ \\
\hline 4 & $X_{\text {rata-ata }}-1,5$ SD & 39.067 & 39.067 & $x$ & $\leq$ & 45.712 & Rendah & 10 & $17.857 \%$ \\
\hline 5 & & & & $\mathrm{x}$ & $\leq$ & 39.067 & Sangat Rendah & 8 & $14.286 \%$ \\
\hline \multicolumn{8}{|c|}{ Jumlah } & 56 & $100 \%$ \\
\hline
\end{tabular}

Berdasarkan tabel 6 mengenai gambaran umum konsentrasi belajar siswa kelas XI DPIB di SMKN 6 Kota Bekasi, dapat dideskripsikan bahwa tingkat konsentrasi belajar pada kategori sangat tinggi sebanyak 12 responden $(21,429 \%)$, kategori tinggi sebanyak 13 responden $(23,214 \%)$, kategori sedang sebanyak 13 responden (23,214\%), kategori rendah sebanyak 10 responden $(17,857 \%)$, dan kategori sangat rendah sebanyak 8 responden $(14,286 \%)$. Dari hasil persentase di atas, maka secara umum dapat diperoleh bahwa tingkat konsentrasi belajar siswa kelas XI program DPIB di SMKN 6 Kota Bekasi cenderung tersebar pada kategori sedang dengan nilai presentase $(23,214 \%)$.

Berikut diagram dan presentase distribusi data variabel tingkat konsentrasi belajar siswa kelas XI program DPIB di SMKN 6 Kota Bekasi berdasarkan sebaran angket.

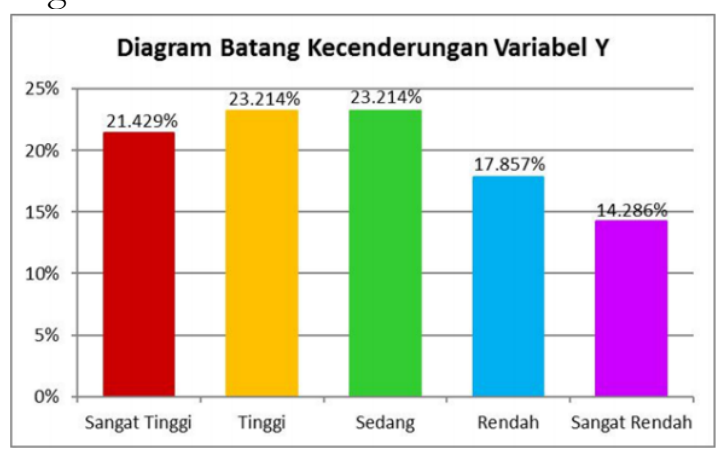

Gambar 4. Diagram Batang Kecenderungan Variabel Y
Deskripsi Hasil Uji Hipotesis

Uji hipotesis pada penelitian ini menggunakana analisis uji korelasi. Karena data yang diperoleh berdistribusi normal maka analisis uji korelasi menggunakan rumus korelasi pearson product moment. Dari hasil perhitungan didapat rhitung $=$ 0,496, berdasarkan pada kriteria penafsiran koefisien korelasi, nilai tersebut terdapat pada rentang 0,400 - 0,599, maka dapat disimpulkan bahwa koefisien korelasi pada penelitian ini termasuk kepada tingkat korelasi cukup kuat.

\section{Perhitungan Koefisien Determinasi}

Berdasarkan hasil perhitungan, diperoleh koefisien determinasi dengan rumus $\mathrm{KD}=\mathrm{r} 2 \times 100 \%$ diperoleh nilai koefisien determinasi sebesar $\mathrm{KD}=0,4962$ $\mathrm{x} 100 \%=24,561 \%$, maka dapat disimpulkan bahwa sumbangan variabel $\mathrm{X}$ terhadap variabel $\mathrm{Y}$ sebesar 24,561\%. Sedangkan sumbangan dari faktor lain terhadap variabel Y sebesar 75,439\%.

Analisis Regresi Sederhana

Perhitungan persamaan regresi linier sederhana digunakan untuk melakukan prediksi seberapa tinggi nilai variabel $\mathrm{Y}$ (konsentrasi belajar) bila nilai variabel $\mathrm{X}$ (suasana lingkungan belajar) dimanipulasi. Tabel 7 merupakan tabel uji korelasi Pearson Product Moment (PPM).

Dari hasil penelitian pada table 7 diolah dengan menggunakan analisis regresi linier sederhana diperoleh persamaan regresi yaitu $\mathrm{Y}=25,220+0,496 \mathrm{X}$. Persamaan ini memberikan informasi bahwa setiap perubahan satu satuan unit nilai suasana lingkungan belajar diikuti oleh perubahan nilai konsentrasi belajar sebesar 25,716 dan memiliki nilai yang positif. Data tersebut menggambarkan terjadinya pengaruh yang positif dari suasana lingkungan belajar terhadap konsentrasi belajar siswa kelas XI program Desain Pemodelan dan Informasi Bangunan SMK Negeri 6 Kota Bekasi. Apabila suasana lingkungan belajar meningkat, maka 
konsentrasi belajar siswa juga akan meningkat.

Tabel 7. Uji Korelasi Pearson Product Moment (PPM)

\begin{tabular}{|c|c|c|c|c|c|}
\hline Responden & $\mathbf{x}$ & $\mathbf{Y}$ & $X^{\wedge} 2$ & $Y^{\wedge} \mathbf{2}$ & $\mathbf{X Y}$ \\
\hline Responden 01 & 52.1 & 53.9 & 2713 & 2906 & 2808 \\
\hline Responden 02 & 42.0 & 34.4 & 1764 & 1184 & 1446 \\
\hline Responden 03 & 37.0 & 41.5 & 1366 & 1723 & 1534 \\
\hline Responden 04 & 48.1 & 52.1 & 2309 & 2718 & 2505 \\
\hline Responden 05 & 58.1 & 44.2 & 3380 & 1950 & 2568 \\
\hline Responden 06 & 40.0 & 40.6 & 1599 & 1650 & 1624 \\
\hline Responden 07 & 59.1 & 53.9 & 3499 & 2906 & 3189 \\
\hline Responden 08 & 47.0 & 40.6 & 2213 & 1650 & 1911 \\
\hline Responden 09 & 32.9 & 45.9 & 1084 & 2110 & 1512 \\
\hline Responden 10 & 42.0 & 45.0 & 1764 & 2029 & 1892 \\
\hline Responden 11 & 48.1 & 51.2 & 2309 & 2627 & 2463 \\
\hline Responden 12 & 59.1 & 60.1 & 3499 & 3613 & 3555 \\
\hline Responden 13 & 57.1 & 62.8 & 3264 & 3940 & 3586 \\
\hline Responden 14 & 29.9 & 38.8 & 894 & 1509 & 1162 \\
\hline Responden 15 & 51.1 & 59.2 & 2609 & 3508 & 3025 \\
\hline Responden 16 & 50.1 & 41.5 & 2507 & 1723 & 2078 \\
\hline Responden 17 & 41.0 & 41.5 & 1681 & 1723 & 1701 \\
\hline Responden 18 & 60.2 & 64.5 & 3619 & 4166 & 3883 \\
\hline Responden 19 & 46.0 & 42.4 & 2120 & 1797 & 1952 \\
\hline Responden 20 & 47.0 & 46.8 & 2213 & 2192 & 2203 \\
\hline Responden 21 & 68.2 & 69.0 & 4655 & 4757 & 4706 \\
\hline Responden 22 & 65.2 & 54.8 & 4251 & 3002 & 3573 \\
\hline Responden 23 & 66.2 & 69.0 & 4383 & 4757 & 4566 \\
\hline Responden 24 & 56.1 & 55.7 & 3150 & 3100 & 3125 \\
\hline Responden 25 & 61.2 & 64.5 & 3741 & 4166 & 3948 \\
\hline Responden 26 & 65.2 & 54.8 & 4251 & 3002 & 3573 \\
\hline Responden 27 & 49.1 & 47.7 & 2407 & 2276 & 2341 \\
\hline Responden 28 & 54.1 & 59.2 & 2927 & 3508 & 3204 \\
\hline Responden 29 & 48.1 & 61.9 & 2309 & 3829 & 2974 \\
\hline Responden 30 & 32.9 & 29.1 & 1084 & 847 & 958 \\
\hline Responden & $\mathbf{X}$ & $\mathbf{Y}$ & $X^{\wedge} \mathbf{2}$ & $Y^{\wedge} 2$ & $\mathbf{X Y}$ \\
\hline Responden 31 & 45.0 & 58.3 & 2028 & 3403 & 2627 \\
\hline Responden 32 & 37.0 & 53.9 & 1366 & 2906 & 1993 \\
\hline Responden 33 & 53.1 & 53.0 & 2819 & 2811 & 2815 \\
\hline Responden 34 & 55.1 & 54.8 & 3038 & 3002 & 3020 \\
\hline Responden 35 & 54.1 & 33.5 & 2927 & 1124 & 1814 \\
\hline Responden 36 & 46.0 & 32.6 & 2120 & 1066 & 1503 \\
\hline Responden 37 & 47.0 & 45.9 & 2213 & 2110 & 2161 \\
\hline Responden 38 & 32.9 & 46.8 & 1084 & 2192 & 1542 \\
\hline Responden 39 & 45.0 & 56.6 & 2028 & 3200 & 2547 \\
\hline Responden 40 & 65.2 & 62.8 & 4251 & 3940 & 4092 \\
\hline Responden 41 & 51.1 & 53.9 & 2609 & 2906 & 2754 \\
\hline Responden 42 & 54.1 & 56.6 & 2927 & 3200 & 3061 \\
\hline Responden 43 & 29.9 & 38.8 & 894 & 1509 & 1162 \\
\hline Responden 44 & 51.1 & 52.1 & 2609 & 2718 & 2663 \\
\hline Responden 45 & 50.1 & 60.1 & 2507 & 3613 & 3010 \\
\hline Responden 46 & 41.0 & \begin{tabular}{l|l}
45.9 \\
\end{tabular} & 1681 & 2110 & 1883 \\
\hline Responden 47 & 60.2 & 39.7 & 3619 & 1579 & 2390 \\
\hline Responden 48 & 36.0 & 55.7 & 1293 & 3100 & 2002 \\
\hline Responden 49 & 41.0 & 47.7 & 1681 & 2276 & 1956 \\
\hline Responden 50 & 55.1 & 50.4 & 3038 & 2537 & 2776 \\
\hline Responden 51 & 57.1 & 48.6 & 3264 & 2361 & 2776 \\
\hline Responden 52 & 54.1 & 49.5 & 2927 & 2448 & 2677 \\
\hline Responden 53 & 39.0 & 39.7 & 1519 & 1579 & 1549 \\
\hline Responden 54 & 61.2 & 68.1 & 3741 & 4636 & 4164 \\
\hline Responden 55 & 65.2 & 34.4 & 4251 & 1184 & 2244 \\
\hline Responden 56 & 59.1 & 33.5 & 3499 & 1124 & 1983 \\
\hline Jumlah & 2800 & 2800 & 145500 & 145500 & 142726 \\
\hline
\end{tabular}

Berdasarkan pembahasan hasil penelitian, suasana lingkungan belajar memiliki pengaruh yang bernilai positif dan signifikan. Hal tersebut berarti bahwa apabila suasana lingkungan belajar mengalami perubahan menjadi lebih baik, maka akan diikuti dengan konsentrasi belajar siswa menjadi lebih baik pula. Dengan ini dapat dikatakan bahwa suasana lingkungan belajar memberikan peranan yang cukup penting bagi siswa dalam meningkatkan konsentrasi belajar siswa di sekolah. Hal tersebut sesuai dengan penelitian yang telah dilakukan oleh Arida Febriyanti dengan judul "Hubungan Suasana Lingkungan Belajar dengan Motovasi Belajar Siswa Kelas V SD Negeri Gugus III Kota Bengkulu". Berdasarkan hasil penelitian menunjukkan bahwa terdapat hubungan yang signifikan antara suasana lingkungan belajar dengan motivasi belajar siswa kelas V SD Negeri Gugus III Kota Bengkulu dan tingkat korelasinya termasuk dalam kategori kuat serta tingkat pengaruhnya sebesar $63.4 \%$ dan selebihnya $36,6 \%$ disebabkan oleh faktor lain. Dalam penelitian ini diperoleh gambaran mengenai suasana lingkungan belajar DPIB di SMKN 6 Kota Bekasi cenderung tersebar pada kategori sedang dengan nilai presentase $(26,786 \%)$. Suasana lingkungan belajar memberikan pengaruh yang positif dan signifikan terhadap konsentrasi belajar siswa kelas XI program Desain Pemodelan dan Informasi Bangunan SMK Negeri 6 Kota Bekasi. Dapat disimpulkan bahwa upaya untuk meningkatkan konsentrasi belajar, siswa harus menjaga keadaan susasana lingkungan belajar agar lebih kondusif dengan menjaga kebersihan di lingkungan sekolah atau menjaga agar suasana lingkungan belajar tidak terlalu berisik. Karena dengan menjaga suasana lingkungan belajar, siswa dapat meningkatkan konsentrasi belajarnya dalam menyimak materi pelajaran yang diberikan oleh tenaga pendidik atau guru. Selain itu, pihak guru sebagai tenaga pendidik dapat memberikan metode pembelajaran yang beragam atau ikut andil dalam menjaga suasana lingkungan belajar agar tetap bersih dan kondusif. Hal tersebut dapat meningkatkan konsentrasi belajar siswa terutama dalam menerima materi pelajaran di sekolah. Dengan membuat suasana lingkungan belajar menjadi lebih kondusif diharapkan 
siswa dapat meningkatkan konsentrasi belajar siswa terutama dalam memahami materi pelajaran yang dijelaskan oleh tenaga pendidik atau guru.

\section{Kesimpulan}

Berdasarkan hasil penelitian dan pembahasan sebelumnya, peneliti dapat menarik beberapa kesimpulan diantaranya sebagai berikut: 1. Berdasarkan hasil analisa dalam penelitian ini, bahwa gambaran umum suasana lingkungan belajar siswa kelas XI program Desain Pemodelan dan Informasi Bangunan SMK Negeri 6 Kota Bekasi tersebar dalam kategori sedang. 2.Berdasarkan hasil Analisa dalam penelitian ini, diperoleh mengenai gambaran umum konsentrasi belajar siswa kelas XI program Desain Pemodelan dan Informasi Bangunan SMK Negeri 6 Bekasi termasuk dalam kategori sedang dan tinggi. 3.Berdasarkan hasil uji hipotesis dalam penelitian ini, diperoleh pengaruh yang signifikan antara suasana lingkungan belajar terhadap konsentrasi belajar siswa pada mata pelajaran produktif kelas XI program Desain Pemodelan dan Informasi Bangunan SMK Negeri 6 Kota Bekasi dengan nilai thitung $=4,193>$ ttabel $=$ 1,673. Selain itu untuk menentukan seberapa besar pengaruh suasana lingkungan belajar terhadap konsentrasi belajar siswa dapat dilihat dari nilai koefisien determinasi $\mathrm{KD}=24,561 \%$ yang artinya suasana lingkungan belajar memberikan pengaruh sebesar 24,561\% terhadap konsentrasi belajar siswa.

\section{Daftar Pustaka}

Arikunto, Suharsimi. (2010). Prosedur Penelitian Suatu Pendekatan Praktik. Jakarta: PT. Rineka Cipta.

Dimyati dan Mudijono. (2013). Belajar dan Pembelajaran. Jakarta: Rineka Cipta.

Emzir. (2009). Metodologi Penelitian Pendidikan Kualitatif dn Kuantitatif. Jakarta: PT. Raja Grafindo Persada.

Febriyanti, Arida. (2014). Hubungan Suasana Lingkungan Belajar dengan Motivasi Belajar Siswa Kelas V SD Negeri Gugus III Kota Bengkulu. Bengkulu: Universitas Bengkulu.

Mulyasa, E. (2009). Implememntasi KTSP Kemandirian Guru dan Kepala Sekolah. Jakarta: Bumi aksara.

Slameto.(2013).Belajar dan faktor-faktor yang mempengaruhinya. Jakarta: Rineka Cipta.

Sudijono, Anas. (2011). Pengantar Statistik Pendidikan. Jakarta: Raja Grafindo Persada.

UU No. 20 Tahun 2003 mengenai sistem pendidikan nasional dalam pasal 3 . Winarni, Endang Widi. (2011). Penelitian Pendidikan. Bengkulu: UNIB Press. 